\title{
Online Learning: Insight into Malaysia University Lecturers' Perspective
}

Ratna Zuarni Ramli, Abdul Halim Ramli, Norlis Osman, Zainon Ismail, Mazni Musa, Hisam Satari

To Link this Article: http://dx.doi.org/10.6007/IJARBSS/v11-i2/9201 ～DOI:10.6007/IJARBSS/v11-i2/9201

Received: 15 December 2020, Revised: 18 January 2021, Accepted: 31 January 2021

Published Online: 17 February 2021

In-Text Citation: (Ramli et al., 2021)

To Cite this Article: Ramli, R. Z., Ramli, A. H., Osman, N., Ismail, Z., Musa, M., \& Satari, H. (2021). Online Learning: Insight into Malaysia University Lecturers' Perspective. International Journal of Academic Research in Business and Social Sciences, 11(2), 1250-1258.

\section{Copyright: (c) 2021 The Author(s)}

Published by Human Resource Management Academic Research Society (www.hrmars.com)

This article is published under the Creative Commons Attribution (CC BY 4.0) license. Anyone may reproduce, distribute, translate and create derivative works of this article (for both commercial and non-commercial purposes), subject to full attribution to the original publication and authors. The full terms of this license may be seen at: http://creativecommons.org/licences/by/4.0/legalcode

\section{Vol. 11, No. 2, 2021, Pg. 1250 - 1258}

Full Terms \& Conditions of access and use can be found at http://hrmars.com/index.php/pages/detail/publication-ethics 


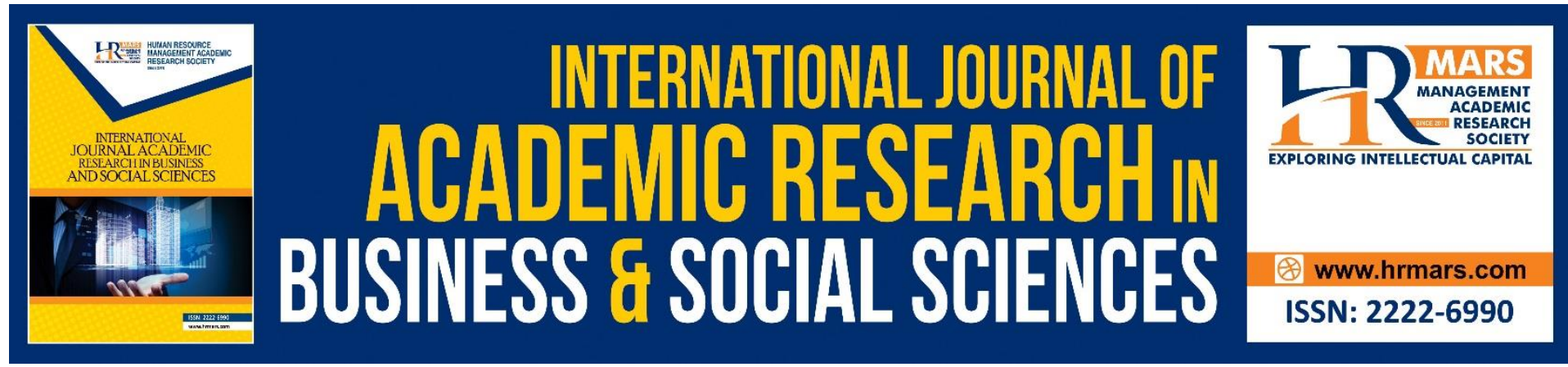

\title{
Online Learning: Insight into Malaysia University Lecturers' Perspective
}

\author{
Ratna Zuarni Ramli, Abdul Halim Ramli, Norlis Osman, Zainon \\ Ismail, Mazni Musa, Hisam Satari \\ Universiti Teknologi MARA, Negeri Sembilan Branch, Malaysia
}

\begin{abstract}
As the role of technology in education is rapidly increasing worldwide, universities in Malaysia have begun responding to online learning and infusing technology in their academic curriculum. The teaching plan aided by technology starts to gain popularity during the COVID19 lockdown as online learning is seen as the main method in providing educational resources to students. However, the plan is never considered successful if the effectiveness of online learning is still questionable. A proper teaching plan is needed to link teachers to their students through customised e-content and resources that can help the teaching and learning process. In addition, the readiness of academicians to venture into online learning and the instability of connectivity in managing the application are also issues to be addressed. Thus, it is important to obtain feedback from lecturers on conducting online learning. This study focuses on Malaysia's academicians at tertiary institutions specifically at Universiti Teknologi MARA, Negeri Sembilan Branch. The objective of the study is to identify the most frequent applications used by lecturers in conducting online classes and the significant correlation between 3 elements; skills, involvement and understanding. Quantitative approach was used in the research involving 462 lecturers from three campuses at UiTM Negeri Sembilan. The result of this study shows Google application is the most favourable application for online learning and there is a positive correlation between lecturers' skills and students' participation. Therefore, it can be concluded that online learning requires commitment from lecturers and students because as lecturers keep updating their teaching skills, students need to adapt and respond accordingly.
\end{abstract}

Keywords: Covid-19, Online Learning, Google Application, Participation, Effectiveness.

\section{Introduction}

The world-wide COVID-19 pandemic has affected not only the global health quality and economy but also the education systems at schools and universities. Lockdown is a common response to control the spread of the virus, thus, the decision to temporarily close education institutions has been imposed by most of the governments around the world. As a result, online learning has become a widespread method for providing education at all levels. In order for the teaching plan to be successful proper plans to connect teachers to their students through customised e-content and resources that can help the teaching and learning process must be established clearly. However, due to the pandemic, teachers have no other option 
but to be ready and competent in utilizing the technology instantly. In addition, the instability of connectivity in managing the application used often are cited as the accompanying woes of teachers and students. Based on Analytic Hierarchical process theory, decision is always made by prioritizing factors that may influence it (Saaty, 1990). Thus, it is important to know the initial decision that was made by academicians in online learning and the implicit factor behind it. This study focuses on Malaysia's academicians in higher institutions specifically at Universiti Teknologi MARA, Negeri Sembilan branch. The objective of the study is to identify the most frequent applications that have been used by lecturers in conducting online classes. While internet connection may be a factor in choosing the application, it is also important to find out the significant correlation between 3 elements; skills, involvement and understanding. The research questions are as follows:

RQ1 What applications are chosen by lecturers in conducting online classes in relation to internet connection?

RQ2 What application has the highest number of active students in online classes?

RQ3 What application chosen by lecturers in conducting online classes in relation to their own techno-skills?

RQ4 Is there a significant correlation between lecturers' techno-skills and students' participation in class?

RQ5 Is there a significant correlation between students' participation in class and the measurement of students' understanding?

\section{Literature Review}

It is a big challenge to academicians, both teachers and students to keep the process of learning thriving during the pandemic. According to UNICEF, $83 \%$ of countries adopted digital broadcasting as a replacement medium of teaching and learning even though $31 \%$ of school children have weak to no-access to digital form. However, studies have shown teachers' lack of skills and usage limited students' skill and usage even when there is a lot of access available (Thorvaldsen \& Madsen, 2020; Al Bataineh, 2015; Miller \& Warschauer et al., 2014). This shows an insignificant relation between teachers' skills and internet connection, but a significant relationship between teachers' skills and students' skills. For teachers, there are various technologies that can support them in the classroom such as tablets, smart boards, Internet and social media, gamification, online quizzes, or group collaboration. Nevertheless, it does not always come with training or manuals that can show the teachers how to effectively use the technologies in their teaching. In addition, with limited amounts of time to plan properly, the idea of bringing education online successfully can be impossible to achieve.

Online learning requires commitment from both teachers and students in order to be effective and successful. E-learning has helped expand Universiti Teknologi Malaysia students' academic experience and satisfaction in its usage during learning which affect the e-learning effectiveness and students' willingness in using e-learning in their studies (Al-Rahmi et al., 2015). A research investigating the e-learning readiness of University Malaya students towards a blended learning model also shows that it is crucial for universities to identify students' needs and readiness before implementing online distance learning (Adams et al., 2018). The readiness of both teachers and students can be seen from their online actions; for example, if teachers put more efforts on teaching through the applications (skills), students may show greater commitment to participate in online class.

In order to facilitate an effective e-learning environment, the perception of teachers on e-learning in terms of the benefits and barriers has been studied in Malaysia as well as in 
other countries. Cheok et al. (2017) used Technology Acceptance Model (TAM) to assess teachers' initial acceptance of technology. They also studied the accessibility and availability of computers, the Internet connection, as well as the programs/training to introduce technology in the teaching process. The findings showed that teachers are satisfied with the current FROG Virtual Learning Environment (VLE) technology provided by the Ministry of Education as it helps to make their teaching easier compared to the traditional approach. Nonetheless, the challenge is the level of technical skills and time needed to study and prepare materials that can capture students' interest and attention and run the e-learning simultaneously. Nearly all the teachers complained of poor Internet connection in implementing e-learning.

Technology supports teaching and learning using digital learning tools such as computer and mobile devices have expanded learning experiences for the students as they enable them to access learning material without any limitations. The changes in the education landscapes help students to develop 21st century skills as well as increase their engagement and motivation. A student's role has changed from being a passive learner to an active learner now. Consequently, a teacher faces new challenges in delivering his or her subject matter for stepping into a virtual class is not the same as going into a physical class.

\section{Methodology}

A set of online questionnaires using google form is designed as the instrument for this study. It contains two parts; demographic and online learning questions. The first part has five questions such as name, faculty, campus, subject and group. The second part of the questionnaire contains 6 questions with 5 Likert-point. At the end of the questionnaires the respondents need to identify any problems or issues encountered during the online class. The initial aim of the survey is to monitor the daily academic activities by all academic staff at UiTM Negeri Sembilan; however, later it has been updated to suit the objective of the study.

The respondents are lecturers from Universiti Teknologi MARA, Negeri Sembilan Branch consisting of Kuala Pilah, Seremban and Rembau campuses. They need to sign in using a formal google account in order to take part in the survey. It is compulsory for all lecturers to fill in the online survey form on a weekly basis as they are reminded through email to do so at the end of the week by the Academic Affairs Department and closely monitored by Heads of Study Centre and Coordinators. Descriptive analysis is then used to evaluate the data using percentage and correlation values.

\section{Result}

The duration of data collection is 9 weeks and in total the survey form collected 15,122 entries with approximate 1,600 data per week. The number of respondents remains at 462 and each respondent is required to fill in the survey according to the number of online classes that one has conducted for a week. The result of the study is discussed based on the research questions.

RQ1 What applications are chosen by lecturers in conducting online classes in relation to internet connection?

The respondents need to rate their internet connection speed from 1(slowest/ low) to 5 (fastest/ high). Based on the result, there are differences in the choices of application used in conducting teaching and learning through online class in relation to high internet connection (3-5 Likert Point) and low internet connection (1-2 Likert Point) as shown in Table 1 and Table 2. Respondents with high speed internet connection prefer to use social media 
applications while those with low speed connection prefer to use Learning Management System (LMS). Nevertheless, Google application is the most frequent application used regardless of the speed of internet connection.

Table 1: Application vs high internet connection

\begin{tabular}{|c|l|c|}
\hline Rank & Application & Percentage \\
\hline 1 & Google Application & 61.7 \\
\hline 2 & Social Media & 28.2 \\
\hline 3 & LMS & 5.9 \\
\hline 4 & Microsoft application & 4.2 \\
\hline
\end{tabular}

Table 2: Application vs low internet connection

\begin{tabular}{|c|l|c|}
\hline Rank & \multicolumn{1}{|c|}{ Application } & Percentage \\
\hline 1 & Google Application & 52.2 \\
\hline 2 & LMS & 19.8 \\
\hline 3 & Social Media & 19.2 \\
\hline 4 & Microsoft application & 8.8 \\
\hline
\end{tabular}

RQ2 What application has the highest number of active students in online classes?

One of the 5-Likert point questions asked is "From 1 (inactive) to 5 (active), please rate students' participation in online classes." The descriptive analysis results showed the highest number of active participations by students in social media applications, followed by LMS and Google application with the same result (3.99/5) and Microsoft Application coming last. Table 3 shows the whole result.

Table 3: Application vs Number of Students' Participation

\begin{tabular}{|c|l|c|}
\hline Rank & Application & Average rate of Students' Participation \\
\hline 1 & Social Media & 4.1 \\
\hline 2 & LMS and Google Application & 3.8 \\
\hline 3 & Microsoft Application & 3.6 \\
\hline
\end{tabular}

RQ3 What application is chosen by lecturers in handling online classes in relation to their own techno-skills?

For this question, respondents are required to rate their own skills in using the applications for their online classes using a Likert scale. 1 for minimum skill and 5 for maximum skill. The result in Table 4 indicates that most of the lecturers are highly skillful in Google Application while less skillful in Microsoft Application for their online classes.

Table 4: Application vs Lecturers' Skills

\begin{tabular}{|l|l|l|}
\hline Rank & Application & Average rate of Lecturers' Skill \\
\hline 1 & Google Application & 4.21 \\
\hline 2 & Social Media & 4.14 \\
\hline 3 & LMS & 4.11 \\
\hline 4 & Microsoft Application & 4.01 \\
\hline
\end{tabular}


RQ4 Is there any/a significant correlation between lecturers' techno-skills and students' participation in class?

Since respondents need to rate their own skills in using applications to conduct online classes, they also need to rate the level of students' participation in class. Students' attendance is not considered as participation. Lecturers must rate using a Likert scale again with 1 for no response and 5 for active participation based on responses from students throughout the classes. A descriptive analysis of over 15000 feedback from the respondents is used to calculate the correlation value between techno-skills and students' participation in class. The result indicates there is moderate positive correlation between the two parameters with the value of 0.61 . Figure 1 shows the histogram of correlation between lecturers' skills and students' participation.

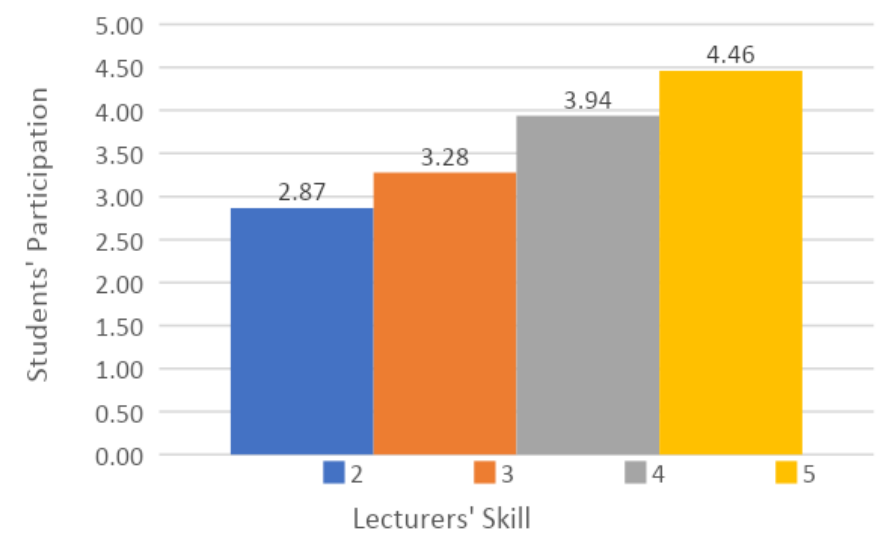

Figure 1: Lecturers' skills vs Students' participation

RQ5 Is there any/a significant correlation between students' participation in class and the measurement of students' understanding?

To answer RQ5, the respondents need to rate two items; the first item is the level of students' participation from 1 as passive participation to 5 as active participation. The second item is the level of the ease to measure students' understanding. Students' understanding can be measured by how students react to class activities and their performance through formative assessments. A descriptive analysis is used to calculate the correlation value on these two items and the result shows a moderate positive correlation with the value of 0.63 . Figure 2 shows the histogram of correlation between these two variables.

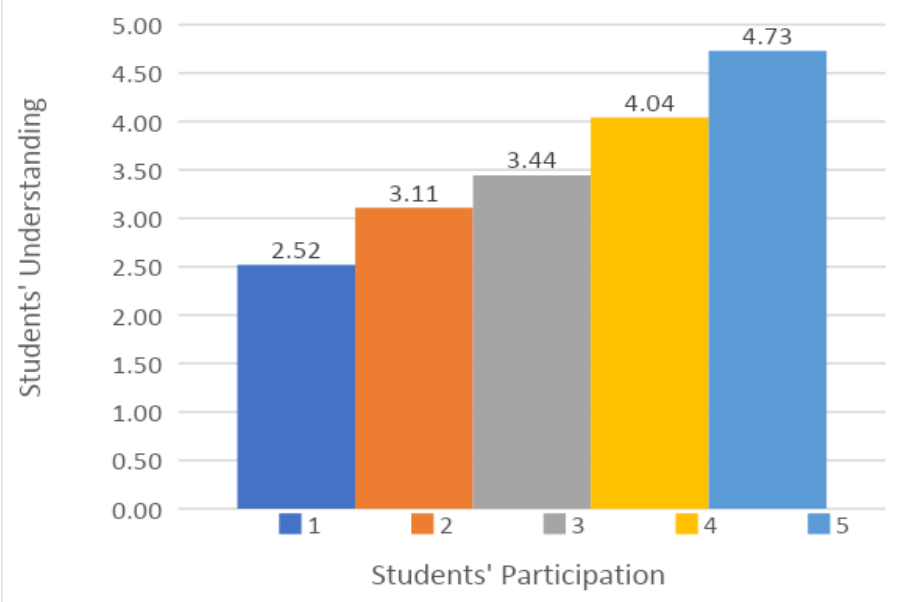

Figure 2 Students' Participation vs Students' Understanding 


\section{Discussion}

There are many researches done to evaluate the use of e-learning applications especially during the lockdown (Satish et al., 2020; Hassan et al., 2020; Aini et al., 2020). Most of the studies show that google applications are easy to use to support online learning. Microsoft applications are one of the top applications used in online learning but google applications are still the most favorable applications (Satish et al., 2020). Usefulness and easiness of using google applications are two of the main factors why students and teachers chose the application over the others (Kumar, 2020). The results showed by other researchers are also supported by this study as google application is the most frequent application used in online learning, both during strong and weak internet connection. It is interesting to find that LMS is the second most popular application used during weak internet connection, while social media (whatsApp, facebook, telegram, instagram) is chosen as the second top application during strong internet connection. According to some studies, whatsApp is identified as a successful application to support e-learning (Komsoon, 2019; Dahdal, 2020). These findings meet the result of the study for RQ2 as online learning through social media shows highest attendance by $10 \%$ over the other applications. However, because of unorganized messages in the application, LMS and google applications are chosen especially during weak internet connection.

Google application is widely used not only for educational purposes but also for industrial deals. The application has been familiar to Malaysian academicians since 2012 and it is reasonable to consider it as the main application in online learning during the lockdown. Thus, the outcome of the study shows that based on lecturers' skills, google application is the most favourable while the least is Microsoft Application. Microsoft application specifically Microsoft Teams is a new discovery to UiTM Negeri Sembilan staff and students. With minimal experience and exposure, not many lecturers prefer to utilize the application for online learning.

E-learning requires commitment from both teachers and students in order to be effective and successful. From the perspective of lecturers, being ready to commit can be considered as an ability to improve the online teaching skills immediately in order to grasp students' attention to the course. From the students' point of view, giving commitment can be seen in how they adjust to the way of learning and how they respond to lecturers. Many studies have been done and the findings show that the main factor of successfulness of online learning is both students and lecturers are ready to implement the virtual education (Adams et al., 2018; Al-Rahmi et al., 2015). Thus, the results of the study to answer RQ4 is parallel to previous studies where there is a positive correlation between lecturers' skills and students' participation.

Students' understanding can be measured by formative and summative assessment. Lecturers can evaluate students' performance to identify their level of understanding. It is difficult to identify the students' understanding based on a single class. Therefore, it takes a few class meetings before the lecturers can initiate a summative assessment and more time to mark and categorize the students based on their performance. In a face-to-face traditional classroom, experienced lecturers are able to observe students' understanding or performance through facial expression or body language. However, it is quite impossible to observe the students' understanding via online learning especially when there is no video or audio response from the students. Thus, in this study, the lecturers were asked to rate how easy (5-point Likert scale) or difficult (1-point Likert scale) to measure their students' understanding. Based on the result, the findings showed that the correlation between 
students' participation and measurement of students' understanding is positively related. It means that if the students actively participate in class activities, it will be easier for the lecturer to identify their level of their understanding.

\section{Conclusion and Future Work}

The government's commitment to excellence in education has been a driving force despite the challenges in infrastructure, resources, implementation and planning at the management and administrative level. The Malaysian Education Blueprint is a detailed plan of action that maps out the education landscape for the period of 2013-2025. One of the initiatives is to require up to $70 \%$ of the curriculum to use blended learning models which has made online learning an essential component of higher education and lifelong learning (Malaysian Education Blueprint 2013-2025). On the brighter side of the pandemic and lockdown, the objective of the Malaysian Education Blueprint is soon to be achieved. However, the effectiveness of online learning is still under review and many more studies need to be done on multiple aspects. This study is one of the initiatives and just an initial research to understand the perspective of lecturers in conducting online class. Another study on the effectiveness of online learning will be carried out to correlate lecturers' and students' perspectives and the final grade of the students.

\section{References}

Adams, D., Sumintono, B., Mohamed, A., \& Noor, N. S. M. (2018). E-Learning Readiness among Students of Diverse Backgrounds in a Leading Malaysian Higher Education Institution. Malaysian Journal of Learning and Instruction, 15(2), 227-256.

Aini, Q., Budiarto, M., Putra, P. O. H., \& Rahardja, U. (2020). Exploring E-learning Challenges During the Global COVID-19 Pandemic: A Review. Jurnal Sistem Informasi, 16(2), 57-65.

Al Bataineh, M., \& Anderson, S. (2015). Jordanian social studies teachers' perceptions of competency needed for implementing technology in the classroom. Contemporary Educational Technology, 6(1), 38-61.

Al-Rahmi, W. M., Othman, M. S., \& Mi Yusuf, L. (2015). The Effectiveness of Using E-Learning in Malaysian Higher Education: A Case Study Universiti Teknologi Malaysia. Mediterranean Journal of Social Sciences, 6(5), 625.

Cheok, M. L., Wong, S. L., Ayub, A. F., \& Mahmud, R. (2017). Teachers' Perceptions of ELearning in Malaysian Secondary Schools. Malaysian Online Journal of Educational Technology, 5(2), 20-33.

Dahdal, S. (2020). Using the WhatsApp Social Media Application for Active Learning. Journal of Educational Technology Systems, 49(2), 239-249. https://doi.org/10.1177/0047239520928307

Koomson W. K. (2020) Ontology of Ubiquitous Learning: WhatsApp Messenger Competes Successfully with Learning Management Systems (LMS). In: Arai K., Kapoor S. (eds) Advances in Computer Vision. CVC 2019. Advances in Intelligent Systems and Computing, vol 944. Springer, Cham. https://doi.org/10.1007/978-3-030-17798-0_11

Saaty, T. L. (1990) How to Make a Decision: The Analytic Hierarchy Process. European Journal of Operational Research, 48, 9-26.

Salim, K. R., Abdullah, M., Ali, N. L., \& Ali, R. (2018). Usage of Online Learning Resources among Academic Staff at a Malaysian University. International Journal of Engineering \& Technology, 7(3.30), 1-5. 
Sathish, M. T., Sornaganesh, V., Sudha, G., \& Chellama, A. V. (2020). A study on shift of traditional classroom methods to online teaching methods in higher education scenario during lockdown. International Journal of Multidisciplinary Research and Development, 7(7), 86-100.

Thorvaldsen, S., \& Madsen, S. S. (2020). Perspectives on the tensions in teaching with technology in Norwegian teacher education analysed using Argyris and Schön's theory of action. Education and Information Technologies, 25, 5281-5299.

Hassan, W., Ariffin, A., Ahmad, F., Sharberi, S. N. M., Nor Azizi, M. I., \& Zulkiflee, S. N. (2020). Covid-19 pandemic: Langkawi Vocational College Student Challenge in Using Google Classroom for Teaching and Learning. International Journal of Advanced Trends in Computer Science and Engineering, 9(3), 3299-3307 